Materiales de Construcción

Vol. 68, Issue 331, July-September 2018, e162

ISSN-L: 0465-2746

https://doi.org/10.3989/mc.2018.06217

\title{
Behaviour of recycled aggregate concrete under combined compression and shear stresses
}

\author{
K. Liu ${ }^{\mathrm{a}}$, J. Yan ${ }^{\mathrm{a}, \mathrm{b}, \mathrm{c}}$, C. Zou ${ }^{\mathrm{a}, \mathrm{b}, \mathrm{c}} \bowtie$ \\ a. School of Civil Engineering, Harbin Institute of Technology (Harbin, China) \\ b. Key Lab of Structures Dynamic Behaviour and Control of the Ministry of Education1, Harbin Institute of \\ Technology (Harbin, China) \\ c. Key Lab of Smart Prevention and Mitigation of Civil Engineering Disasters of the Ministry of Industry and \\ Information Technology, Harbin Institute of Technology (Harbin, China) \\ \cyzou@hit.edu.cn
}

Received 19 May 2017

Accepted 15 January 2018

Available on line 29 June 2018

\begin{abstract}
To investigate the behaviour of recycled aggregate concrete (RAC) under combined compression and shear stresses, 75 hollow cylinder specimens prepared with various replacement ratios of recycled coarse aggregate (RCA) were tested with a self-designed loading device. The results showed that the failure pattern was similar for RAC with different replacement ratios of RCA. The ultimate shear stress improved with an increasing axial compression ratio of less than 0.6 and declined after exceeding 0.6. A modified failure criterion for $\mathrm{RAC}$ with normal strength under combined compression and shear stresses was proposed. A new procedure to predict the shear strength for RAC beams without stirrups was developed based on the proposed failure criterion, showing a better correlation with the experimental results than the predictions calculated by GB50010, Eurocode 2, fib Model Code 2010 and ACI 318-11.
\end{abstract}

KEYWORDS: Concrete; Waste treatment; Mechanical properties; Modelization.

Citation/Citar como: Liu, K.; Yan, J.; Zou, C. (2018) Behaviour of recycled aggregate concrete under combined compression and shear stresses. Mater. Construcc. 68 [331], e162 https://doi.org/10.3989/mc.2018.06217

RESUMEN: Comportamiento del hormigón con árido reciclado bajo esfuerzos combinados de compresión y cizallamiento. En este estudio, se ensayaron 75 probetas cilíndricas huecas preparadas con distintos porcentajes de sustitución de árido grueso reciclado (RCA) con una máquina de ensayos auto-diseñada con el fin de investigar la resistencia del hormigón con árido reciclado (RAC) a la acción conjunta de los esfuerzos de compresión y de corte. Según los resultados obtenidos, el patrón de fractura del RAC era similar independientemente del porcentaje de sustitución. La resistencia a cortante aumentó hasta una relación de compresión axial de 0.6 y disminuyó a partir de ese valor. En el artículo se propone modificar el criterio de rotura del RAC de resistencia normal ante la acción conjunta de los esfuerzos antedichos. Se ha desarrollado un nuevo procedimiento para predecir la resistencia al corte de las vigas RAC sin estribos basándose en el criterio de rotura propuesto, consiguiéndose una mejor correlación con los resultados experimentales que en el caso de las predicciones calculadas mediante los métodos GB50010, Eurocode 2, fib Model Code 2010 y ACI 318-11.

PALABRAS CLAVE: Hormigón; Tratamiento de residuos; Propiedades mecánicas; Modelización.

ORCID ID: K. Liu (http://orcid.org/0000-0002-8894-6890); J. Yan (http://orcid.org/0000-0002-2781-9046); C. Zou (http://orcid.org/0000-0001-9024-9560)

Copyright: (C) 2018 CSIC. This is an open-access article distributed under the terms of the Creative Commons Attribution 4.0 International (CC BY 4.0) License 


\section{INTRODUCTION}

As sustainable development has become a common concern of mankind, the use of sustainable materials in the construction industry has gained in popularity. With the rapid development of the construction industry, environmental issues, such as the excessive exploitation of natural aggregates and the increasing amount of construction and demolition debris, are increasingly pressing. As a viable way to address demolition waste, recycled aggregate concrete (RAC) can help provide a sustainable construction material and has received considerable attention in many countries over the last several decades (1-2). Although the recycling rate is high in some countries, the use of recycled aggregate is still confined to low-grade applications, such as pavement base, backfill for retaining and hard-core (3-5), which greatly limits the development and application of RAC.

In practical engineering, reinforced concrete elements are frequently subjected to combined compression and shear stresses rather than the uniaxial compression or tension stress state, such as prestressed elements, beams, two-way slabs and shell roofs (6-8). Information on the strength and behaviour of concrete under combined compression and shear stresses becomes important for predicting the performance of these structural members. Bresler et al. (9) investigated the behaviour of concrete hollow cylinders under various combinations of shear and compressive stress and proposed a failure criterion based on the octahedral stress space. Goode et al. (10) compared various failure criteria and indicated that Mohr's theory with the adoption of Leon's parabolic envelope (11) provided a good representation of the failure of concrete under compression and shear stresses. Khaloo et al. (6) summarized the experimental results of combined compression and shear stresses on solid cylinders of normal and high compressive strengths and proposed a strength criterion based on all three stress invariants. Le et al. (12) compared Mohr's theory and the twin shear stress criterion (13) based on the experimental results of Z-shaped specimens and suggested the twin shear stress criterion. Li et al. (14) studied the behaviour of high-strength concrete under combined compression and shear stresses and proposed a failure criterion in terms of the failure criterion proposed by Ottosen (15).
Compared with current studies on conventional concrete, few studies have been conducted for RAC under combined stresses (16-18). As RAC moves toward applications that demand high-performance, such as critical structural elements, it becomes essential to understand its failure under combined loads. To fill in this research gap and facilitate RAC in structural concrete, further research on the behaviour of RAC under combined stresses states must be undertaken to evaluate its performance compared to conventional concrete. This paper presents results from an experimental program to study the failure of hollow-core cylinders of RAC under combined axial load and shear. A modified failure criterion for $\mathrm{RAC}$ with normal strength was proposed. Finally, a new procedure based on the proposed failure criterion to calculate the shear strength of RAC beams without stirrups was developed and validated.

\section{EXPERIMENTAL PROGRAMME}

\subsection{Materials}

Crushed gravel with a maximum diameter of $19 \mathrm{~mm}$ from a local ready-mix concrete plant was used as the natural coarse aggregate (NCA). The parent concrete prepared for the recycled coarse aggregate (RCA) in this programme was made from an abandoned concrete frame in the laboratory (2 years old, with concrete compressive strength of $30 \mathrm{MPa}$ ). The waste concrete was first manually broken into pieces that were smaller than $150 \mathrm{~mm}$. After screening all other materials and debris, the pieces were further crushed in a mini jaw crusher. The crushed RCA was between 4.75 and $19 \mathrm{~mm}$. The particle size distribution of NCA and RCA satisfied the GB/T 14685-2011 (19) and GB/T 25177-2010 (20) gradation requirements, respectively. It should be noted that the original maximum diameter for coarse aggregate was $10 \mathrm{~mm}$ considering the size for hollow cylinders. However, RCA with the maximum diameter of $10 \mathrm{~mm}$ had too much residual mortar and cannot represent the physical properties of normal RCA. Finally, a relative appropriate diameter-19 mm was used in this study. The physical properties for NCA and RCA are shown in Table 1. The apparent density, water absorption, and crushing value of NCA and RCA were tested according to JGJ 52-2006 (21). The residual mortar content, which is a measure of the percent (by weight) of

TABLE 1. Physical properties of NCA and RCA

\begin{tabular}{lcccc}
\hline Type & $\begin{array}{c}\text { Apparent density } \\
\left(\mathbf{k g} / \mathbf{m}^{\mathbf{3}}\right)\end{array}$ & $\begin{array}{c}\text { Water absorption } \\
(\% \text { weight })\end{array}$ & $\begin{array}{c}\text { Crushing value index } \\
(\%)\end{array}$ & $\begin{array}{c}\text { Residual mortar content } \\
(\% \text { weight })\end{array}$ \\
\hline NCA & 2700 & 0.6 & 2.6 & - \\
RCA & 2687 & 6.68 & 12 & 41 \\
\hline
\end{tabular}


TABLE 2. Mixture proportions

\begin{tabular}{|c|c|c|c|c|c|}
\hline ID & Cement $\left(\mathrm{kg} / \mathrm{m}^{3}\right)$ & Water $\left(\mathrm{kg} / \mathrm{m}^{3}\right)$ & Sand $\left(\mathrm{kg} / \mathrm{m}^{3}\right)$ & $\operatorname{NCA}\left(\mathrm{kg} / \mathrm{m}^{3}\right)$ & $\operatorname{RCA}^{a}\left(\mathrm{~kg} / \mathrm{m}^{3}\right)$ \\
\hline NAC & 413 & 215 & 635 & 1081 & 0 \\
\hline RAC30 & 413 & 215 & 635 & 757 & 345 \\
\hline RAC50 & 413 & 215 & 635 & 541 & 574 \\
\hline RAC70 & 413 & 215 & 635 & 325 & 804 \\
\hline RAC100 & 413 & 215 & 635 & 0 & 1148 \\
\hline
\end{tabular}

a The mass for pre-soaked RCA.

residual mortar in the RCA, was determined using the method described by Abbas et al. (22) Ordinary Portland cement P.O 42.5R with a 28-day standard compressive strength of $42.5 \mathrm{MPa}$ and tap water were used for the concrete mix. The fine aggregates consisted of a local natural river sand with a fineness modulus of 2.53 .

\subsection{Concrete mixture proportions}

There is still no standard mix design method for RAC mixture design. Generally, a standard method of mixture design for conventional concrete is adopted in which the NCA is replaced by RCA at different proportions. Three accepted aggregate replacement methods are direct weight replacement, direct volume replacement (DVR) and equivalent mortar volume (EMV) replacement (23-24). However, RAC mixtures made using the EMV method exhibit poor workability, segregation, and honeycombing (25). In this paper, the DVR method was used to prepare RAC. To control the fluidity of RAC, the RCA was pre-soaked for $24 \mathrm{~h}$ to achieve the saturated-surface-dry condition to consider its high water absorption before casting. Table 2 shows the mixture proportions of five mixture designs corresponding to different RCA replacement ratios. NAC represents conventional concrete, RAC30 represents a coarse aggregate replacement ratio of $30 \%$, etc.

\subsection{Specimen design}

The tested specimens consist of hollow cylinders with a $207 \mathrm{~mm}$ outside diameter, $126 \mathrm{~mm}$ inside diameter and $650 \mathrm{~mm}$ height. The cylinders were cast on a shaking table in a longitudinal position in a split steel mould with a demountable polyethylene core. After $24 \mathrm{~h}$, the specimens were demoulded and then cured under normal conditions $\left(20 \pm 2{ }^{\circ} \mathrm{C}\right.$ and $95 \%$ relative humidity).

To load the torque, the end of the cylinder was changed to square shape. The surfaces of both ends with a length of $100 \mathrm{~mm}$ was pockmarked by an electric drill, and then four steel bars were plugged into the holes with a diameter of $12 \mathrm{~mm}$ made at the quartering point $50 \mathrm{~mm}$ from the end. High-strength non-shrinking grouting material was used to fill the square mould and strengthen the ends. Both ends of the cylinders were strengthened by two layers of glass fibre-reinforced polymer wrap to avoid premature failure during the test. The details for the specimen are shown in Figure 1.

A total of 75 cylinders were prepared, 15 for each mixture. Meanwhile, twelve cubes with a side length of $100 \mathrm{~mm}$ were made as the control specimens for each mixture to test the compressive strength and split tensile strength. Table 3 shows the test results for the control specimens.

\subsection{Loading procedure}

The test setup is shown in Figure 2. One end of the cylinder was set on the rotatable support, linked with the torque arm, while the other end was fixed by steel plates. The torque was applied by a closed loop servo-controlled material testing system. The axial loading was applied by using a 60 ton hydraulic jack to tension the prestressed screw-thread steel bar and measured by a pressure sensor. A thrust ball bearing was placed at the loading end of the cylinder to eliminate the frictional restraint induced by rotation.

The force-control method was used during the whole loading programme. An axial compressive loading was applied first to a predetermined level to give compressive stress $\sigma_{\mathrm{x}}$ of $0,0.2,0.4,0.6$ or 0.8 times the axial compressive strength $f_{\mathrm{c}}$. The axial compressive stress was held constant and the torque was then applied monotonically in step loading system until failure occurred. The shear strain was tested by two strain rosettes, adhered to the surface of the specimen and consisting of an axial strain gauge, a lateral one and a diagonal one with an angle of $45^{\circ}$. Two tilt sensors were placed at the side of the specimen to monitor the torque angle and make sure a uniform rotation direction. In addition, the torque was recorded by the electro hydraulic servo system automatically in each loading step. 

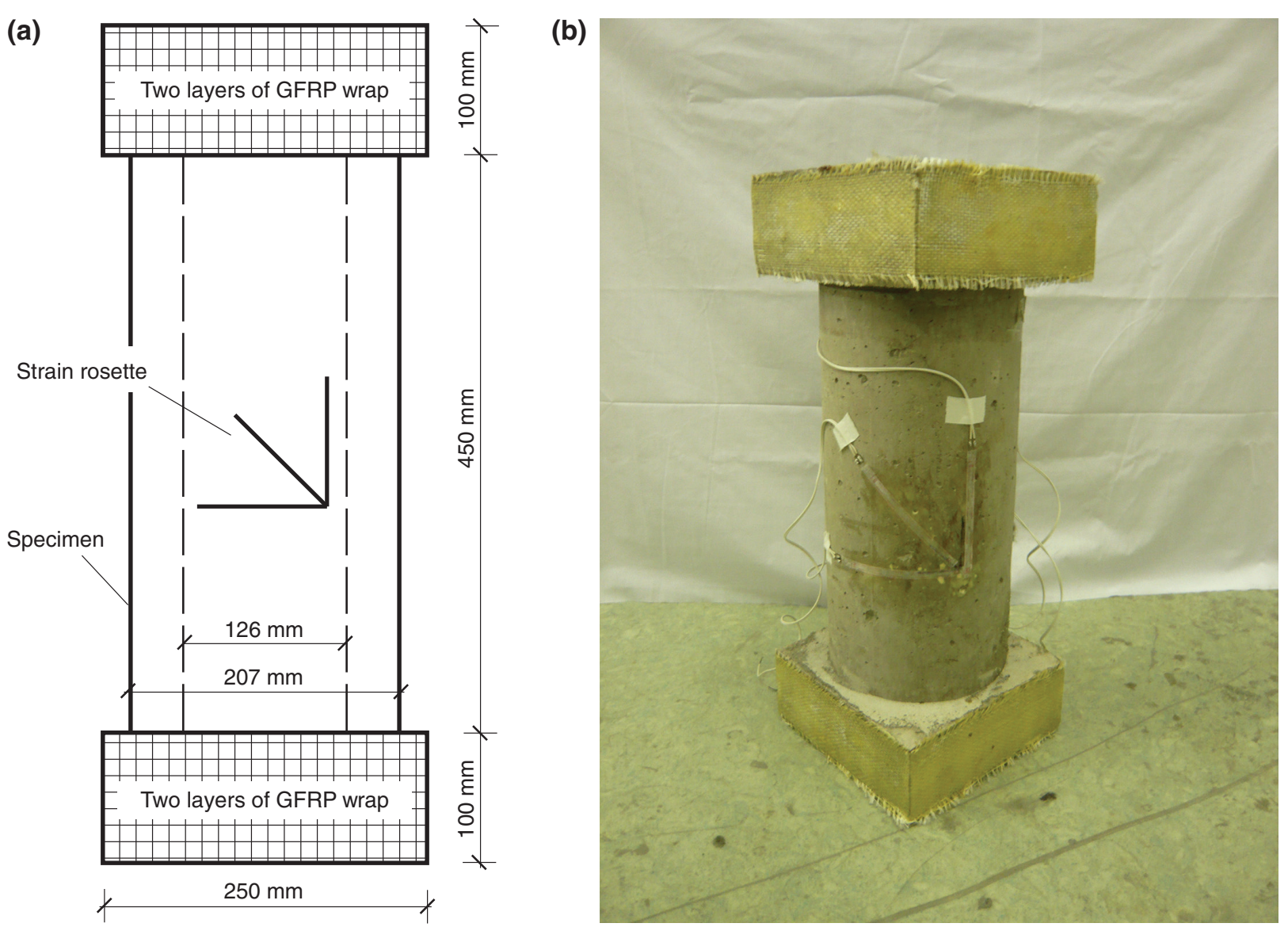

FIgURE 1. Details for the specimen (a) Blueprint (b) Physical map.

TABLE 3. Test results for control specimens

\begin{tabular}{lccc}
\hline ID & Cubic compressive strength $f_{\text {cu }}(\mathbf{M P a})$ & Axial compressive strength $f_{\mathbf{c}}^{\text {a }}(\mathbf{M P a})$ & Split tensile strength $(\mathbf{M P a})$ \\
\hline NAC & 45.63 & 34.68 & 2.89 \\
RAC30 & 34.31 & 26.08 & 2.23 \\
RAC50 & 33.33 & 25.33 & 1.69 \\
RAC70 & 30.79 & 23.40 & 1.69 \\
RAC100 & 30.17 & 22.93 & 1.97 \\
\hline
\end{tabular}

${ }^{a}$ The axial compressive strength was calculated according to GB50152 (26).

\section{RESULTS AND DISCUSSION}

\subsection{Failure patterns}

The failure patterns for all mixtures were similar. The five typical failure modes for RAC100 series are illustrated in Figure 3. One principal diagonal crack forming approximately $45^{\circ}$ to the longitudinal axis was observed for the specimens under pure torsion. As the axial compression ratio $\sigma_{\mathrm{x}} / f_{\mathrm{c}}$ increased, the angle $\theta$ of the diagonal crack to the longitudinal axis gradually decreased. Some short cracks developed and connected with the principal crack at failure for specimens with $\sigma_{\mathrm{x}} / f_{\mathrm{c}}$ of 0.8 .

\subsection{Shear stress versus shear strain curves}

A previous study indicated that the shearing stress of a hollow cylinder can be assumed as a linear distribution along the thickness (9). The ratio between average shear stress and maximum shear stress in the cross section is 0.81 for this test, which indicated that the maximum shear stress can be used to represent the shear stress in the specimen (27). 
(a)

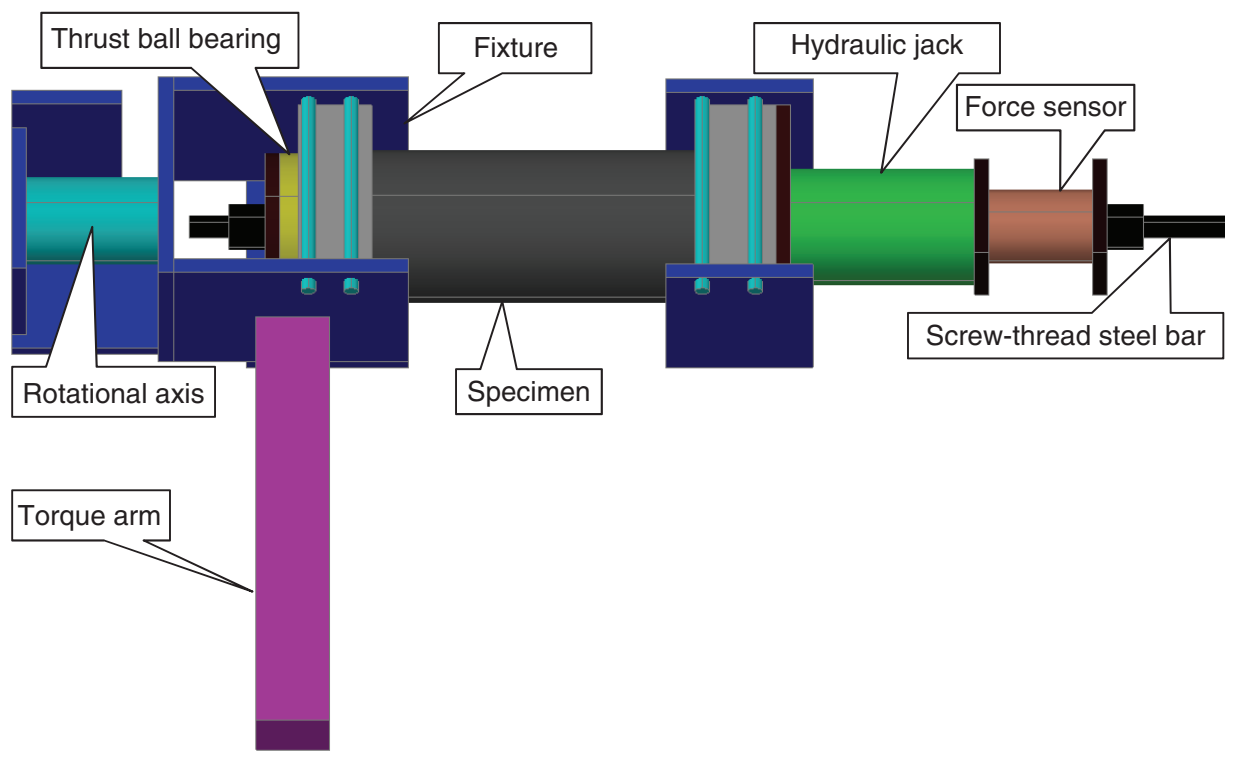

(b)

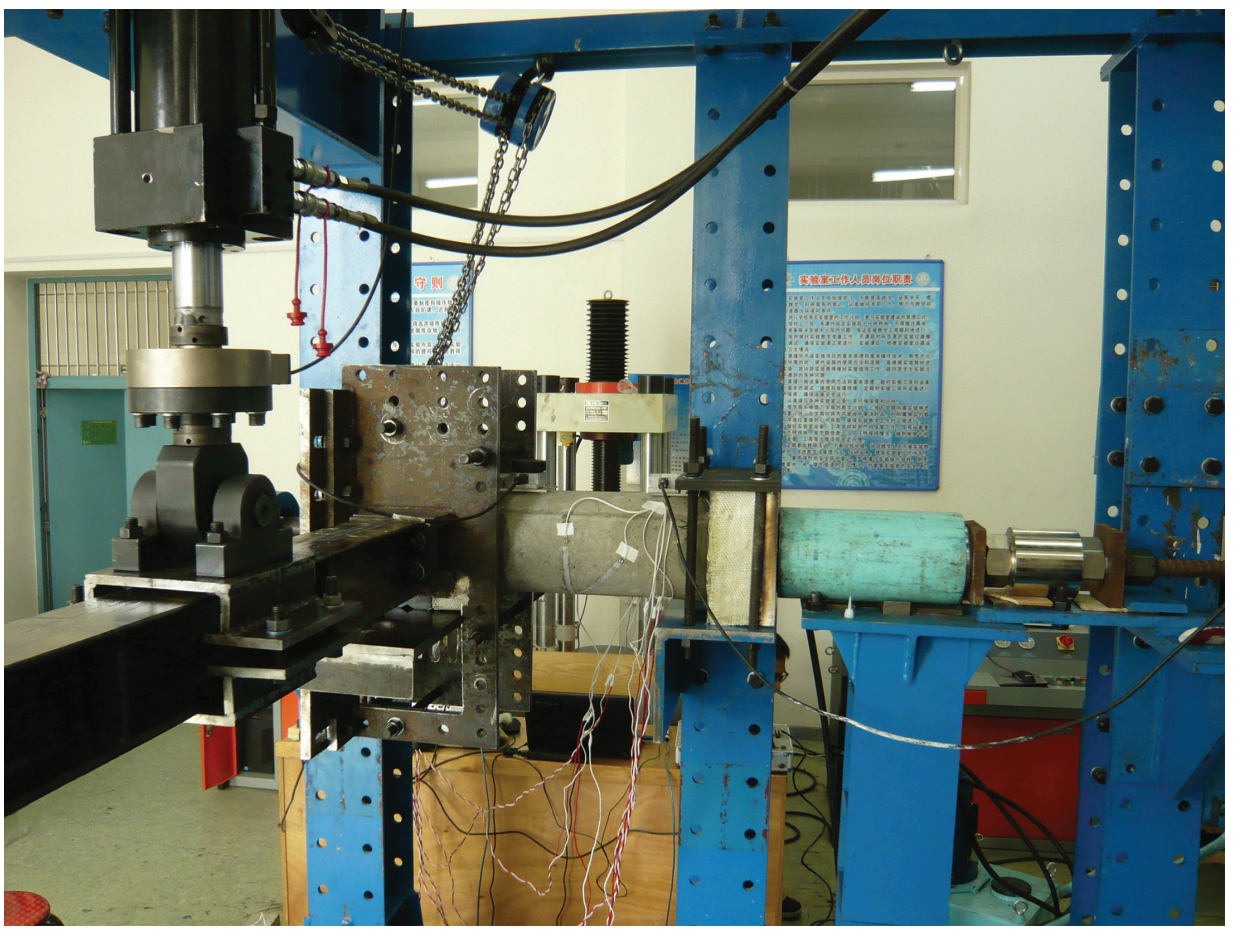

Figure 2. Test setup (a) Schematic drawing (b) Physical map.

The shear stress and shear strain can be calculated as follows [Eq. 1 and 2]:

$$
\begin{aligned}
& \tau=\frac{16 T}{\pi D^{3}\left[1-(d / D)^{4}\right]} \\
& \gamma=2 \varepsilon_{45^{\circ}}-\left(\varepsilon_{0^{\circ}}+\varepsilon_{90^{\circ}}\right)
\end{aligned}
$$

where $\tau=$ shear stress, MPa; $T=$ applied torque, $\mathrm{kN} \cdot \mathrm{m} ; d=$ inside diameter of hollow cylinder, $\mathrm{mm}$;
$D=$ outside diameter of hollow cylinder, $\mathrm{mm}$; $\gamma=$ shear strain, $\mu \varepsilon ; \varepsilon_{0^{\circ}}=$ axial strain, $\mu \varepsilon ; \varepsilon_{45^{\circ}}=$ diagonal strain, $\mu \varepsilon$; and $\varepsilon_{90^{\circ}}=$ lateral strain, $\mu \varepsilon$.

The typical shear stress versus shear strain curves are listed in Figure 4. The curves for all specimens showed a near linear relationship during most of the loading history. The ultimate shear stress and shear stiffness increased with increasing axial compression ratio when the ratio was below 0.6 and declined when the ratio exceeded 0.6. This can be explained by the fact that the favourable behaviour of limiting 

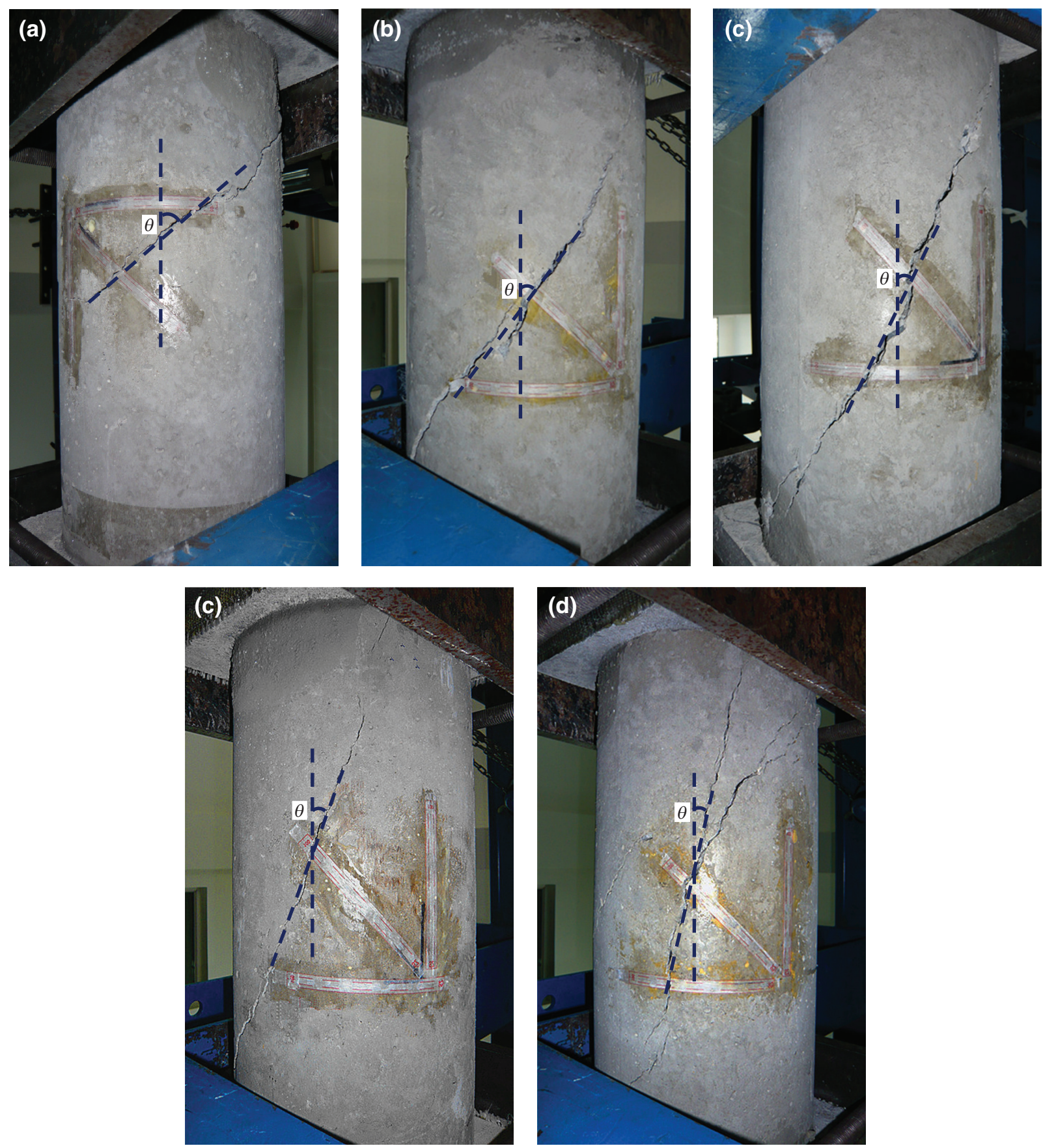

FIgURE 3. Typical failure modes for RAC100 series.

the development of cracks and enhancing the shear capacity due to axial compressive stress dominated the damage induced thereby when the axial compression ratio was below 0.6. However, once the ratio exceeded 0.6 , the cracks caused by high axial compressive stress began to develop unsteadily, which reduced the bearing capacity of the specimen. A summary of the experimental results for ultimate shear stress is given in Table 4 .

\section{A FAILURE CRITERION FOR RAC UNDER COMBINED COMPRESSION AND SHEAR STRESSES}

Under the plane stress condition, the combined compression and shear stresses state can be transformed to a tensile-compression stress state (Figure 5). The conversion equations can be expressed as follows [Eq. 3 and 4] : 

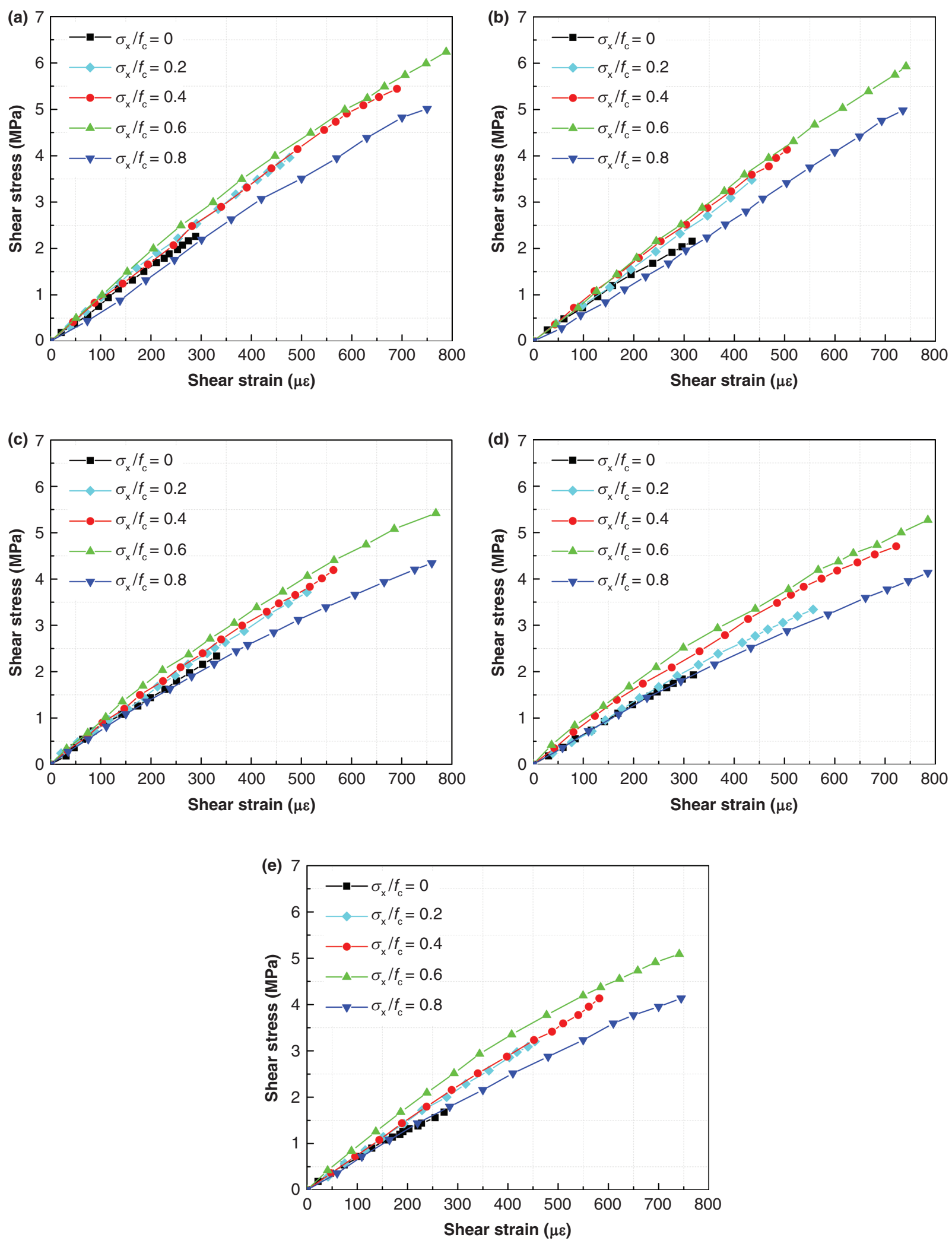

FIGURE 4. Shear stress versus shear strain curves. (a) NAC (b) RAC30 (c) RAC50 (d) RAC70 (e) RAC100. 
TABLE 4. A summary of shear stress $\tau$ (MPa)

\begin{tabular}{|c|c|c|c|c|c|}
\hline \multirow[b]{2}{*}{$\sigma_{\mathrm{x}} l f_{\mathrm{c}}$} & \multicolumn{5}{|c|}{ ID } \\
\hline & NAC & RAC30 & RAC50 & RAC70 & RAC100 \\
\hline \multirow[t]{3}{*}{0} & 2.24 & 1.97 & 2.45 & 1.82 & 1.79 \\
\hline & 2.31 & 2.33 & 1.80 & 1.78 & 1.80 \\
\hline & 2.22 & 1.95 & 1.74 & 1.93 & 1.88 \\
\hline \multirow[t]{3}{*}{0.2} & 3.96 & 3.64 & 3.95 & 3.31 & 3.46 \\
\hline & 4.67 & 3.89 & 3.98 & 3.34 & 3.96 \\
\hline & 4.07 & 3.52 & 2.62 & 4.40 & 2.43 \\
\hline \multirow[t]{3}{*}{0.4} & 5.11 & 4.36 & 4.76 & 2.91 & 3.80 \\
\hline & 5.88 & 3.92 & 4.32 & 4.70 & 4.31 \\
\hline & 5.27 & 4.45 & 3.44 & 5.06 & 4.00 \\
\hline \multirow[t]{3}{*}{0.6} & 6.24 & 5.76 & 5.85 & 4.76 & 5.28 \\
\hline & 6.32 & 6.14 & 5.89 & 5.45 & 4.17 \\
\hline & 4.97 & 5.23 & 5.42 & 5.29 & 4.19 \\
\hline \multirow[t]{3}{*}{0.8} & 5.01 & 5.02 & 4.79 & 5.24 & 3.80 \\
\hline & $-^{\mathrm{a}}$ & 4.28 & 4.34 & 4.50 & 4.32 \\
\hline & - & 5.12 & - & - & - \\
\hline
\end{tabular}

a ‘_' represents missing data.

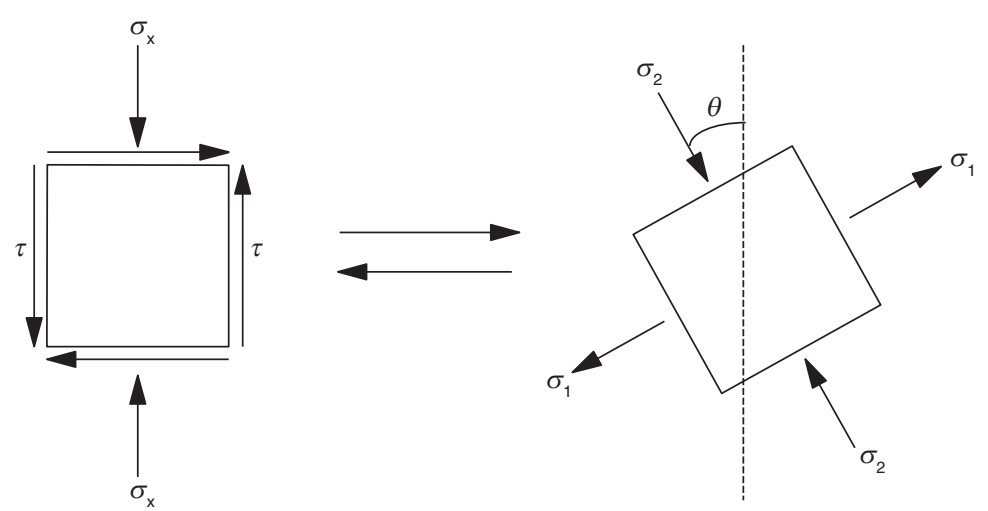

FIGURE 5. Transformation between two stress states.

$$
\begin{aligned}
& \sigma_{1}=\sigma_{\mathrm{x}} / 2+\sqrt{\left(\sigma_{\mathrm{x}} / 2\right)^{2}+\tau^{2}} \\
& \sigma_{2}=\sigma_{\mathrm{x}} / 2-\sqrt{\left(\sigma_{\mathrm{x}} / 2\right)^{2}+\tau^{2}}
\end{aligned}
$$

where $\sigma_{1}=$ principal tensile stress, MPa; and $\sigma_{2}=$ principal compressive stress, $\mathrm{MPa}$.

The angle $\theta$ between $\sigma_{2}$ and the longitudinal axis can be calculated as follows [Eq. 5] :

$$
\tan 2 \theta=-2 \tau / \sigma_{\mathrm{x}}
$$

It can be seen from Eq. [5] that $\theta$ was $45^{\circ}$ for the specimens under pure shear stress and decreased as the compressive stress increased. This was consistent with the change of the angle between the principal diagonal crack and the longitudinal axis (Figure 3).

Based on Eq. [3] and Eq. [4], the failure criterion for concrete under principal stresses state can be translated into that under combined compression and shear stresses state. Therefore, four classical strength criteria, Leon theory (11), Kupfer criterion (28), twin shear stress criterion (13) and Bresler theory (9), were selected to compare with the experimental results. The details of the transformation of the four failure criteria can be seen in the Appendix. A total of 65 effective test results were selected according to GB/T50081 (29). Table 5 shows the average ratios between predictions and experimental results. Leon theory and the twin shear stress criterion agreed well with the test results 
TABLE 5. Average Ratios between predictions and experimental results

\begin{tabular}{lcccc}
\hline & \multicolumn{3}{c}{ Failure criteria } \\
\cline { 2 - 5 } ID & Leon & Twin shear stress & Kupfer & Bresler \\
\hline NAC & 1.40 & 1.27 & 1.08 & 1.04 \\
RAC30 & 1.19 & 1.15 & 0.89 & 0.93 \\
RAC50 & 1.01 & 0.91 & 0.78 & 1.03 \\
RAC70 & 0.91 & 0.75 & 1.01 \\
RAC100 & 0.98 & 0.84 & 0.74 & 1.03 \\
\hline
\end{tabular}

of RAC compared with NAC, while the Kupfer criterion was just the opposite. In addition, the Kupfer criterion cannot give the strength of concrete under pure stress due to its limitation. The Bresler theory show better consistency with the test values than the others.

Based on the previous analysis, Bresler theory was selected to establish the failure criterion for RAC under combined compression and shear stresses in plane stress space. To make a failure criterion suitable for both NAC and RAC with normal strength, a unified formula was proposed based on experimental results and can be expressed as follows [Eq. 6]:

$$
\tau / f_{\mathrm{c}}=\eta \sqrt{\begin{array}{l}
k_{1}^{\prime}+k_{2}^{\prime}\left(\sigma_{\mathrm{x}} / f_{\mathrm{c}}\right)+k_{3}^{\prime}\left(\sigma_{\mathrm{x}} / f_{\mathrm{c}}\right)^{2} \\
+k_{4}^{\prime}\left(\sigma_{\mathrm{x}} / f_{\mathrm{c}}\right)^{3}+k_{5}^{\prime}\left(\sigma_{\mathrm{x}} / f_{\mathrm{c}}\right)^{4}
\end{array}}
$$

where $\eta=$ a coefficient related to the replacement ratio of RCA. The parameters $\eta, k_{1}^{\prime}, k_{2}^{\prime}, k_{3}^{\prime}, k_{4}^{\prime}$ and $k_{5}^{\prime}$ can be determined by a multiple nonlinear regression analysis, and Eq. [6] was then expressed as follows [Eq. 7] :

$$
\tau / f_{\mathrm{c}}=\left(\begin{array}{l}
-0.049 \omega^{2} \\
+0.065 \omega+0.1
\end{array}\right) \sqrt{\begin{array}{l}
0.421+4.936\left(\sigma_{\mathrm{x}} / f_{\mathrm{c}}\right) \\
+3.591\left(\sigma_{\mathrm{x}} / f_{\mathrm{c}}\right)^{2} \\
-6\left(\sigma_{\mathrm{x}} / f_{\mathrm{c}}\right)^{3} \\
-2.948\left(\sigma_{\mathrm{x}} / f_{\mathrm{c}}\right)^{4}
\end{array}}
$$

where $\omega=$ the replacement ratio of RCA.

Figure 6 gives the comparison between the resulting values and the theoretical values calculated by the proposed failure criterion. No other test results were used for comparison because experimental studies on the behaviour of RAC under combined compression and shear stresses are very limited. The $\mathrm{R}$-square for all mixtures were larger than 0.90 , indicating that the proposed failure criterion compared favourably with the experimental results. From Eq. [7], it can be seen that the normalized ultimate shear stress $\tau / f_{\mathrm{c}}$ increased with the increasing $\omega$ of less than $70 \%$ and declined after exceeding $70 \%$. However, even for RAC with 100\% replacement of recycled coarse aggregate, the $\tau / f_{\mathrm{c}}$ was still larger than that of NAC.

\section{APPLICATION OF THE PROPOSED FAILURE CRITERION}

The failure criterion is an effective approach to determine the capacity of reinforced concrete structures under various conditions of loading. As an indication of the possibility of applying the proposed failure criterion for RAC, a method for calculating the shear strength of normal RAC beams without stirrups was developed. The following conventional assumptions were made in advance:

1. Concrete cannot resist tension.

2. Failure occurred by the destruction of concrete in the shear-compression zone.

3. The shear strength of the RAC beam $V_{\text {beam }}$ was provided by three parts: concrete $V_{c}$, aggregate interlock capacity $V_{\mathrm{a}}$, and dowel resistance of the longitudinal reinforcement $V$ s.

Figure 7 shows the typical distribution of internal force for a simply supported beam. The shape of the distribution for the shear stress and the direct stress were both the curved type.

To simplify the process, the average shear stress $\tau_{\mathrm{m}}$ and direct stress $\sigma_{\mathrm{m}}$ were used for representing the real stress state, and the force equilibrium equation can be expressed as follows [Eq. 8, 9 and 10] :

$$
\begin{gathered}
V_{\text {beam }}=V_{\mathrm{c}}+V_{\mathrm{a}}+V_{\mathrm{s}} \\
V_{\mathrm{c}}=\tau_{\mathrm{m}} b h_{\xi} \\
\sigma_{\mathrm{m}} b h_{\xi}=\sigma_{\mathrm{s}} \rho b h_{0}
\end{gathered}
$$

where $b=$ web width of the section, $\mathrm{mm} ; h_{\xi}=$ depth of the shear-compression zone, $\mathrm{mm} ; \sigma_{\mathrm{s}}=$ tensile stress of longitudinal reinforcement, $\mathrm{MPa} ; \rho=$ reinforcement 
$10 \cdot \mathrm{K}$. Liu et al.
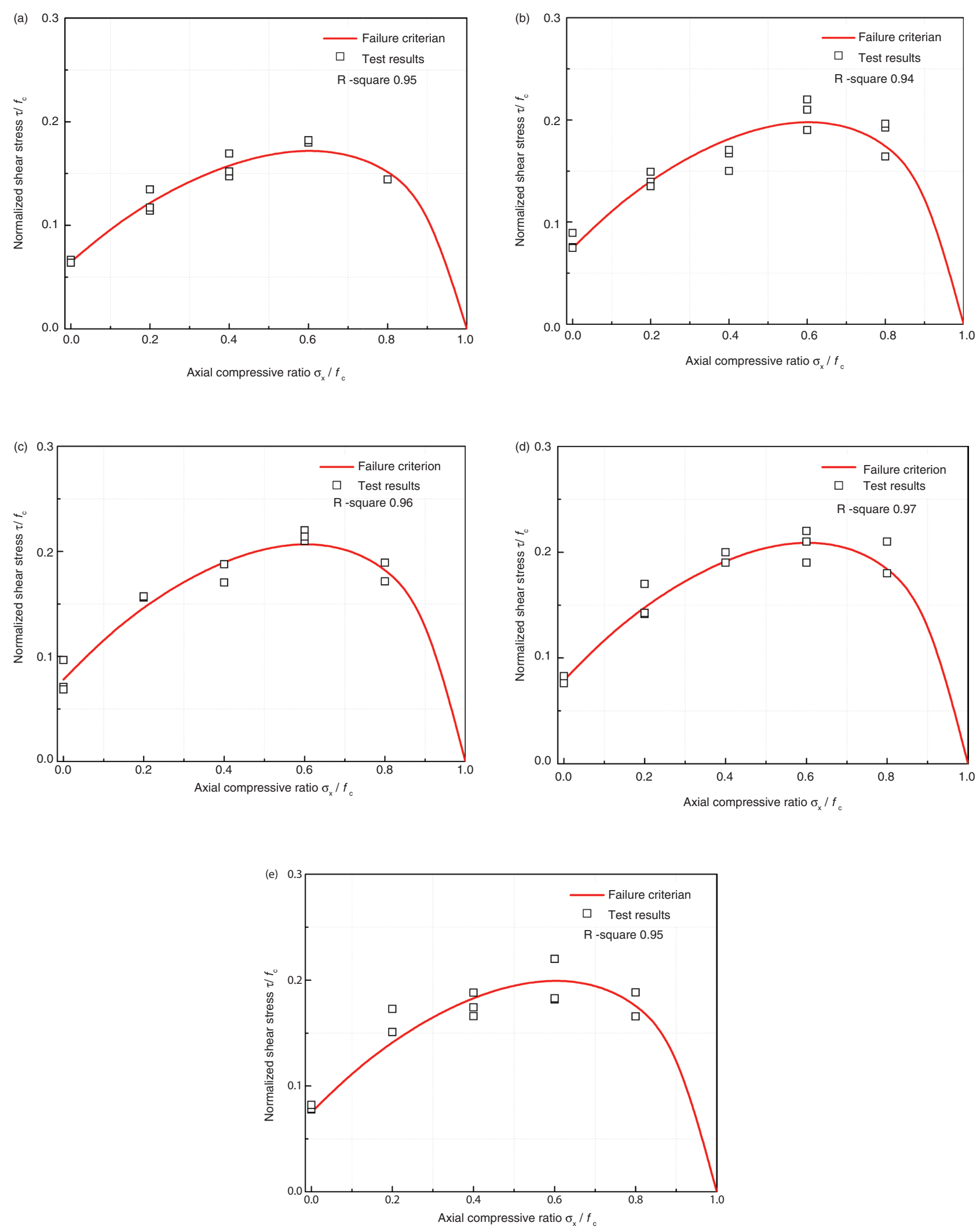

FIGURE 6. Comparison between test results and predictions of proposed failure criterion. (a) NAC (b) RAC30 (c) RAC50 (d) RAC70 (e) RAC100. 


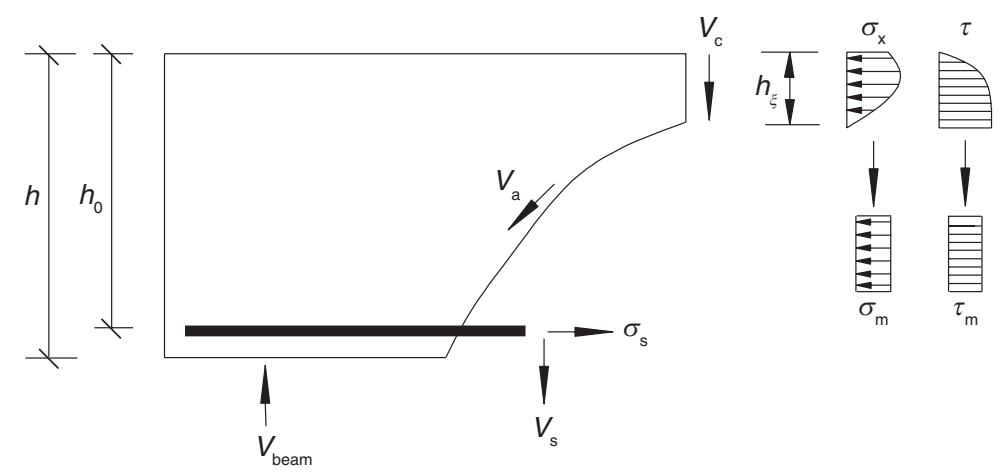

FIGURE 7. Distribution of internal force for a simply supported beam.

ratio of longitudinal bars; and $h_{0}=$ distance from extreme compression fibre to centroid of longitudinal reinforcement, $\mathrm{mm}$. $V_{\mathrm{a}}$ and $V_{\mathrm{s}}$ can be expressed by the following equation (30) [Eq. 11]:

$$
V_{\mathrm{a}}+V_{\mathrm{s}}=\mu V_{\text {beam }}
$$

where $\mu$ was a proportionality. For concrete beams without stirrups, $m$ can be set as 0.5 (31). Luo et al. (32) proposed a method to determine $h_{\xi}$, which can be expressed as follows [Eq. 12] :

$$
h_{\xi}=\left\{\begin{array}{cr}
30 f_{\mathrm{c}}^{-0.5} \rho^{0.6} \lambda^{-1} h_{0} & 1 \leq \lambda<3 \\
10 f_{\mathrm{c}}^{-0.5} \rho^{0.6} h_{0} & 3 \leq \lambda
\end{array}\right.
$$

where $\lambda=$ shear span to depth ratio. The tensile stress $\sigma_{\mathrm{s}}$ for the longitudinal bar can be calculated by the following formula (31) [13]:

$$
\left.\sigma_{\mathrm{s}}=(0.395 \lambda-0.152) f_{\mathrm{c}} /[(1.524+\lambda) \rho)\right]
$$

Once $\sigma_{\mathrm{s}}$ was obtained, $\sigma_{\mathrm{m}}$ can be determined by Eq. [10] and plugged into Eq. [7] to calculate $\tau_{\mathrm{m}}$. Then, $V_{\mathrm{c}}$ was obtained from Eq. [9]. Finally, the shear strength $V_{\text {beam }}$ was determined by Eq. [8].

Table 6 shows the comparison between the test results $V_{\text {beam }}$ of 20 beams exhibiting shear compression failure (33-35) and predictions $V_{\text {pre. }}$. In addition to the method proposed in this paper, GB50010 (36), Eurocode 2 (37), Level III Approximation of fib Model Code 2010 (38) and ACI 318-11 (39) were also introduced. The predictions calculated by GB50010, Eurocode 2, Level III Approximation of fib Model Code 2010 and ACI 318-11 were relatively conservative compared with the results by the failure criterion, especially for ACI 318-11. The ratios for the method proposed in this paper had an average ratio of 0.96 , and 85 percent of the predicted values were in the range of 0.82 to 1.20 , showing good correlation with the experimental results, especially for the beams in Fathifazl's test. It should be noted that compared with the test results for the shear behaviour of conventional concrete beams without stirrups, those for RAC beams were limited. More studies can be done to verify the proposed model in the future.

\section{CONCLUSIONS}

The behaviour of RAC under combined compression and shear stresses was investigated experimentally in this paper. The following conclusions are drawn:

1. The failure patterns for all mixtures were similar. As the axial compressive stress increased, the angle of the diagonal crack to the longitudinal axis gradually decreased.

2. The ultimate shearing stress and shear stiffness increased with increasing axial compression ratio when the ratio was below 0.6 and declined when the ratio exceeded 0.6 .

3. A modified failure criterion for both NAC and RAC under combined compression and shear stresses was proposed, showing good matching with the test results.

4. A new method for determining the shear strength of RAC beams without stirrups was developed based on the failure criterion, showing a good correlation with the test results.

\section{Appendix}

\section{Leon theory}

Leon (11) suggested a parabola as the envelope to Mohr's circles for brittle materials whose 
TABLE 6. Ratios between $V_{\text {per }}$ and $V_{\text {beam }}$ of selected beams

\begin{tabular}{|c|c|c|c|c|c|c|c|}
\hline \multirow[b]{2}{*}{ Investigator } & \multirow[b]{2}{*}{ Specimen ID } & \multirow[b]{2}{*}{$\begin{array}{c}\text { RCA } \\
\begin{array}{c}\text { Replacement } \\
\text { ratio }\end{array}\end{array}$} & \multicolumn{5}{|c|}{$V_{\text {per }} / V_{\text {beam }}$} \\
\hline & & & $\begin{array}{l}\text { Proposed } \\
\text { failure } \\
\text { criterion }\end{array}$ & GB50010 & Eurocode 2 & $\begin{array}{l}\text { fib Model } \\
\text { Code } 2010\end{array}$ & ACI 318-11 \\
\hline \multirow{7}{*}{$\begin{array}{l}\text { Zhang et al. } \\
\text { (2007) }\end{array}$} & LC-2.5-0 & $0 \%$ & 1.20 & 0.97 & 0.47 & 0.76 & 0.24 \\
\hline & LR-2.5-1 & $100 \%$ & 1.46 & 0.97 & 0.48 & 0.78 & 0.24 \\
\hline & LC-1.5-0 & $0 \%$ & 0.74 & 0.41 & 0.17 & 0.23 & 0.14 \\
\hline & LR-1.5-1 & $100 \%$ & 1.07 & 0.51 & 0.24 & 0.45 & 0.18 \\
\hline & LR-1.5-0.3 & $30 \%$ & 0.90 & 0.42 & 0.19 & 0.27 & 0.15 \\
\hline & LR-1.5-0.5 & $50 \%$ & 0.91 & 0.42 & 0.18 & 0.26 & 0.15 \\
\hline & LR-1.5-0.7 & $70 \%$ & 1.00 & 0.44 & 0.21 & 0.33 & 0.16 \\
\hline \multirow{4}{*}{$\begin{array}{l}\text { Fathifazl et al. } \\
\text { (2009) }\end{array}$} & EM-1.5N & $63.5 \%$ & 1.04 & 0.66 & 0.35 & 0.59 & 0.33 \\
\hline & EM-2N & $63.5 \%$ & 0.97 & 0.70 & 0.44 & 0.83 & 0.36 \\
\hline & $\mathrm{EV}-1.5 \mathrm{~N}$ & $74.3 \%$ & 0.94 & 0.72 & 0.36 & 0.66 & 0.33 \\
\hline & EV-2N & $74.3 \%$ & 1.06 & 0.82 & 0.43 & 0.87 & 0.35 \\
\hline \multirow{9}{*}{$\begin{array}{l}\text { Ni et al. } \\
(2010)\end{array}$} & BH0 & $0 \%$ & 0.67 & 0.80 & 0.38 & 0.67 & 0.36 \\
\hline & BH25-1 & $25 \%$ & 0.83 & 0.85 & 0.37 & 0.69 & 0.37 \\
\hline & BH25-2 & $25 \%$ & 0.90 & 0.92 & 0.40 & 0.54 & 0.40 \\
\hline & BH25-3 & $25 \%$ & 0.82 & 0.84 & 0.37 & 0.74 & 0.36 \\
\hline & BH50-1 & $50 \%$ & 0.96 & 0.82 & 0.40 & 0.54 & 0.37 \\
\hline & BH50-2 & $50 \%$ & 0.90 & 0.77 & 0.38 & 0.64 & 0.35 \\
\hline & BH50-3 & $50 \%$ & 0.94 & 0.80 & 0.40 & 0.56 & 0.37 \\
\hline & BH75-1 & $75 \%$ & 0.96 & 0.82 & 0.41 & 0.53 & 0.38 \\
\hline & BH75-3 & $75 \%$ & 0.96 & 0.81 & 0.41 & 0.53 & 0.38 \\
\hline
\end{tabular}

compressive strength is more than five times their tensile strength, which can be expressed as follows:

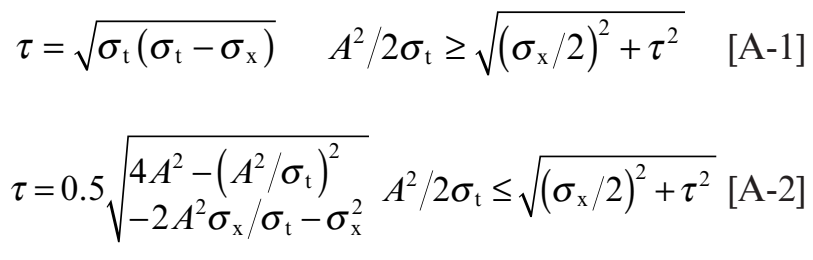

where $A=\sqrt{\sigma_{\mathrm{t}}\left(\sigma_{\mathrm{t}}+\sigma_{\mathrm{c}}\right)}-\sigma_{\mathrm{t}}, \sigma_{\mathrm{t}}$ and $\sigma_{\mathrm{c}}$ are the numerical values of the uniaxial tensile and compressive strengths, respectively.

2. Twin shear stress criterion

The twin shear stress theory was proposed by $\mathrm{Yu}$ et al. (13) and can be expressed as follows:

$$
\begin{array}{ll}
F=\tau_{12}+\tau_{13} \beta\left(\sigma_{13}+\sigma_{12}\right)+a \sigma_{\mathrm{h}}=c & F \geq F^{\prime} \\
F^{\prime}=\tau_{13}+\tau_{23} \beta\left(\sigma_{13}+\sigma_{12}\right)+a \sigma_{\mathrm{h}}=c & F \geq F^{\prime}
\end{array}
$$

where $\tau_{13}=$ the maximum principle shear stress; $\tau_{12}, \tau_{23}=$ the other two principle shear stresses, $\beta=$ an influencing parameter; $c=$ a parameter related to strength of material; $F=$ equivalent stress, $\sigma_{\mathrm{h}}=$ hydrostatic pressure; and $a=$ a parameter related to $\sigma_{\mathrm{h}}$. The parameters $\beta, a$ and $c$ can be expressed as follows:

$$
\begin{gathered}
\beta=(\bar{\alpha}+2 \alpha-3 \alpha \bar{\alpha}) /[\bar{\alpha}(1+\alpha)] \\
a=-6 \alpha(\bar{\alpha}-1) /[\bar{\alpha}(1+\alpha)] \\
c=2 \alpha \sigma_{\mathrm{c}} /(1+\alpha)
\end{gathered}
$$

Where $\alpha=\sigma_{t} / \sigma_{c}, \bar{\alpha}=\sigma_{\mathrm{bc}} / \sigma_{\mathrm{c}}$, and $\sigma_{\mathrm{bc}}$ is the biaxial compressive strength. In addition,

$\tau_{12}=\left(\sigma_{1}-\sigma_{2}\right) / 2 ; \tau_{13}=\left(\sigma_{1}-\sigma_{3}\right) / 2 ; \tau_{23}=\left(\sigma_{2}-\sigma_{3}\right) / 2$

$\sigma_{12}=\left(\sigma_{1}+\sigma_{2}\right) / 2 ; \sigma_{13}=\left(\sigma_{1}+\sigma_{3}\right) / 2 ; \sigma_{23}=\left(\sigma_{2}+\sigma_{3}\right) / 2[$

Therefore, the twin shear stress theory can be described in the principal stress space:

$$
\begin{gathered}
F=\sigma_{1}-\left(\sigma_{2}+\sigma_{3}\right) / 2+\beta\left[\sigma_{1}+\left(\sigma_{2}+\sigma_{3}\right) / 2\right] \\
+a\left(\sigma_{1}+\sigma_{2}+\sigma_{3}\right) / 3=\mathrm{c} \quad F \geq F
\end{gathered}
$$




$$
\begin{aligned}
& F^{\prime}=-\sigma_{3}+\left(\sigma_{1}+\sigma_{2}\right) / 2+\beta\left[\sigma_{3}+\left(\sigma_{1}+\sigma_{2}\right) / 2\right] \\
& \quad+a\left(\sigma_{1}+\sigma_{2}+\sigma_{3}\right) / 3=\mathrm{c} \quad F \geq F
\end{aligned}
$$

The twin shear stress theory can then be transformed as follows:

$$
\tau=\min \left(\begin{array}{l}
\sqrt{\left\{\left[2 c-\sigma_{\mathrm{x}}(A+B)\right] /[2(A-B)]\right\}^{2}}, \\
\sqrt{\left\{\left[\sigma_{\mathrm{x}} / 2\right)^{2}\right.} \\
\left.\left.-\left(2 c-\sigma_{\mathrm{x}}\left(A_{\mathrm{x}} / 2\right)^{2}+B^{\prime}\right)\right] /\left[2\left(A^{\prime}-B^{\prime}\right)\right]\right\}^{2}
\end{array}\right)
$$

Where $A, B, A^{\prime}$ and $B^{\prime}$ are four parameters that can be expressed as follows:

$$
\begin{aligned}
& A=1+\beta+a / 3 ; B=-1 / 2+\beta / 2+a / 3 ; \\
& A^{\prime}=1 / 2+1 / 2 \beta+a / 3 ; B^{\prime}=-1+\beta+a / 3
\end{aligned}
$$

\section{Kupfer criterion}

Kupfer et al. (28) proposed a failure criterion for concrete under the tensile-compression stress state, which can be expressed as follows:

$$
\begin{gathered}
\sigma_{1} / \sigma_{3}>0 \\
\sigma_{1}=\left(1-0.8 \sigma_{3} / f_{\mathrm{c}}\right) f_{\mathrm{t}}
\end{gathered}
$$

This can be rewritten in terms of the applied stresses $\sigma_{\mathrm{x}}$ and $\tau$ :

$$
\begin{gathered}
\sigma_{\mathrm{x}}=\sigma_{1}+\sigma_{3} \\
\tau=\sqrt{\sigma_{1} \sigma_{3}}
\end{gathered}
$$

\section{Bresler theory}

Bresler et al. (9) proposed a failure criterion for concrete in the octahedral stress space, which can be expressed as follows:

$\tau_{\mathrm{oct}} / f_{\mathrm{c}}=k_{1}+k_{2} \sigma_{\mathrm{oct}} / f_{\mathrm{c}}+k_{3}\left(\sigma_{\mathrm{oct}} / f_{\mathrm{c}}\right)^{2}$

where $\tau_{\text {oct }}$ is octahedral shear stress; $\sigma_{\text {oct }}$ is octahedral normal stress; $k_{1}, k_{2}$ and $k_{3}$ are parameters.

This can be rewritten in terms of the applied stresses $\sigma_{\mathrm{x}}$ and $\tau$ :

$$
\tau / f_{\mathrm{c}}=\sqrt{\begin{array}{l}
k_{1}^{\prime}+k_{2}^{\prime}\left(\sigma_{\mathrm{x}} / f_{\mathrm{c}}\right)+k_{3}^{\prime}\left(\sigma_{\mathrm{x}} / f_{\mathrm{c}}\right)^{2} \\
+k_{4}^{\prime}\left(\sigma_{\mathrm{x}} / f_{\mathrm{c}}\right)^{3}+k_{5}^{\prime}\left(\sigma_{\mathrm{x}} / f_{\mathrm{c}}\right)^{4}
\end{array}}
$$

Where $k_{1}^{\prime}, k_{2}^{\prime}, k_{3}^{\prime}, k_{4}^{\prime}$ and $k_{5}^{\prime}$ are parameters.

\section{ACKNOWLEDGEMENTS}

The work described in this paper was supported by a grant from the National Natural Science Foundation of China (grant number 51278151).

\section{REFERENCES}

1. Hansen, T.C. (1986) Recycled aggregates and recycled aggregate concrete second state-of-the-art report developments 1945-1985. Mater \& Struct. 19[3], 201-246. https:// doi.org/10.1007/BF02472036.

2. Vázquez, E. (2013) Progress of recycling in the built environment: final report of the RILEM Technical Committee 217-PRE, Springer, Netherlands.

3. Choi, W.; Kim, S.; Yun, H. (2012) Flexural performance of reinforced recycled aggregate concrete beams. Mag Concrete Res. 64[9], 837-848. https://doi.org/10.1680/macr.11.00018.

4. Silva, R.V.; Brito, J.; Dhir, R.K. (2014) Properties and composition of recycled aggregates from construction and demolition waste suitable for concrete production. Constr Build Mater. 65, 201-217. https://doi.org/10.1016/j. conbuildmat.2014.04.117.

5. Tam, V.W.Y.; Wang, Z.; Tao, Z. (2014) Behaviour of recycled aggregate concrete filled stainless steel stub columns. Mater \& Struct. 47[1-2], 293-310. https://doi.org/10.1617/ s11527-013-0061-1.

6. Khaloo, A.R.; Ahmad, S.H. (1988) Behavior of normal and high-strength concrete under combined compressionshear loading. ACI Mater J. 85[6], 551-559.

7. Bentz, E.C.; Vecchio, F.J.; Collins, M.R. (2006) Simplified modified compression field theory for calculating shear strength of reinforced concrete elements. ACI Struct J. 103[4], 614-624.

8. Marcantonio, P.R.; Ozbolt, J.; Petrangeli, M. (2015) Rational approach to prediction of shear capacity of RC beam-column elements. ASCE J Struct Eng. 141[2], http:// doi.org/10.1061/(ASCE)ST.1943-541X.0001037.

9. Bresler, B.; Pister, K.S. (1958) Strength of concrete under combined stresses. ACI Journal Proceedings. ACI, US, 321-345.

10. Goode, C.D.; Helmy, M.A. (1967) The strength of concrete under combined shear and direct stress. Mag Concrete Res. 19[59], 105-112. https://doi.org/10.1680/ macr.1967.19.59.105

11. Leon, A. (1935) Ueber die scherfestigkeit des betons. Beton und Eisen. 34[8], 130-135.

12. Le, F.; Dong, Y.; Zhang, L. Kang, G. (1996) Behavior of concrete under combined compression-shear loading. Journal of Fuzhou University (Natural Science). 24[S1], 30-35.

13. Yu, M.; Liu, F. (1988) Twin shear stress three parameter criterion and its corner model. China Civil Engineering Journal. 2[3], 90-95.

14. Li, J. (1997) Behavior of high-strength concrete under combined compression and shear loading. China Civil Engineering Journal. 30[3)], 74-80.

15. Ottosen, N.S. (1977) A failure criterion for concrete. $A S C E$ Engineering Mechanics Division. 103[4], 527-535.

16. Folino, P.; Xargay, H. (2014) Recycled aggregate concrete-mechanical behavior under uniaxial and triaxial compression. Constr Build Mater. 56, 21-31. http://doi. org/10.1016/j.conbuildmat.2014.01.073.

17. He, Z; Cao, W.; Zhang, J.; Wang, L. (2015) Multiaxial mechanical properties of plain recycled aggregate concrete. Mag Concrete Res. 67[8], 401-413. https://doi.org/10.1680/ macr.14.00262.

18. He, Z; Liu, G.; Cao, W.; Zhou, C.; Zhang, J. (2015) Strength criterion of plain recycled aggregate concrete under biaxial compression. Comput Concrete, 16[2], 209-222. https://doi. org/10.12989/cac.2015.16.2.209.

19. GB/T 14685 (2011) Pebble and crushed stone for construction. Chinese National Standard.

20. GB/T 25177 (2010) Recycled coarse aggregate for concrete. Chinese National Standard.

21. JGJ 52 (2006) Standard for technical requirements and test method of sand and crushed stone (or gravel) for ordinary concrete. Chinese Industry Standard.

22. Abbas, A.; Fathifazl, G.; Fournier, B.; Isgor, O.B.; Zavadil, R.; Razaqpur, A.G.; Foo, S. (2009) Quantification of the residual mortar content in recycled concrete aggregates by image analysis. Mater Charact. 60[7], 716-728. https://doi. org/10.1016/j.matchar.2009.01.010. 
23. Fathifazl, G.; Abbas, A.; Razaqpur, A.G.; Isgor, O.B. (2009) New mixture proportioning method for concrete made with coarse recycled concrete aggregate. ASCE J Mater Civil Eng. 21[10], 601-611. http://doi.org/10.1061/ (ASCE)0899-1561(2009)21:10(601)

24. Knaack, A.M.; Kurama, Y.C. (2011) Design of normal strength concrete mixtures with recycled concrete aggregates. ASCE In Structures Congress. Las Vegas, United States, 3068-3079. https://doi.org/10.1061/41171(401)267.

25. Surya, M.; Rao, V.V.L.K.; Lakshmy, P. (2015) Mechanical, durability, and time-dependent properties of recycled aggregate concrete with fly ash. ACI Mater J. 112[5], 653661. https://doi.org/10.14359/51687853.

26. GB/T 50152 (2012) Standard for test method of concrete structures. Chinese National Standard.

27. Guo, Z. (1997) Strength and deformation of concrete: Experimental basis and constitutive model. Beijing, China.

28. Kupfer, H.; Hilsdorf, H.K.; Rusch, H. (1969) Behavior of concrete under biaxial stresses. ACI In ACI Journal proceedings. US, 656-666.

29. GB/T 50081 (2002) Standard for test method of mechanical properties on ordinary concrete. Chinese National Standard.

30. Swamy, R.; Qureshi, S. (1974) An ultimate shear strength theory for reinforced concrete T-beams without web reinforcement. Mater. Construcc. 7[3], 181-189. http://doi. org/10.1007/BF02473833.
31. Gao, D.; Liu, J.; Li, Z. (1994) Theoretical model on shear strength of reinforced fiber concrete beams. Engineering Mechanics. 11[2], 130-137.

32. Luo, L.; Wang, Q. (2013) Shear strength formula for reinforced concrete beams without web reinforcements against size effect. Applied Mathematics and Mechanics. 34[6], 606-619.

33. Zhang, L.; Zhang, X.; Yan, G. (2007) Experimental research on the shearing capacity of recycled concrete beams without stirrups. Industrial Construction. 37[9], 57-61.

34. Fathifazl, G.; Abbas, A.; Razaqpur, A.G.; Foo, S. (2009) Shear strength of reinforced recycled concrete beams without stirrups. Mater \& Struct. 61[7], 477-490. https://doi. org/10.1680/macr.2008.61.7.477.

35. Ni, T.; Sun, W.; Guo, Z. (2010) Experimental study on shear behavior of recycled concrete beams without stirrup. Sichuan Building Science, 36[1], 5-7.

36. GB/T 50010 (2010) Code for design of concrete structures. Chinese National Standard.

37. NP EN 1992-1-1 Eurocode 2 (2010) Design of concrete structures-Part 1: general rules and rules for buildings. British Standards Institution.

38. fib (2013) fib Model Code for Concrete Structures 2010. Ernst \& Sohn $G m b H \&$ Co. KG, Germany.

39. ACI 318-11 (2011) Building code requirements for structural concrete and commentary. American Concrete Institute, USA. 